\title{
List of Photographs Taken in Galilee, with Descriptions
}

\section{H. H. Kitchener}

To cite this article: H. H. Kitchener (1878) List of Photographs Taken in Galilee, with

Descriptions, Palestine Exploration Quarterly, 10:3, 134-141, DOI: 10.1179/peq.1878.10.3.134

To link to this article: http://dx.doi.org/10.1179/peq.1878.10.3.134

曲 Published online: 20 Nov 2013.

Submit your article to this journal $\pi$

Џ Article views: 7

Q View related articles $\longleftarrow$ 


\section{IIST OF PHOTOGRAPHS TAKEN IN GALILEE, WITH DESCRIPTIONS.}

I. Kunl'at Tibnîn, the Crusading Castle of Toron.-The view is taken from the south-west across the pool of water near the village, and gives a view of the whole of the western side of the fortress. The existing walls are Arabic work built by Dhahr el 'Amr, but the foundation and some of the interior vaults of Crusading masonry still remain. The entrance is seen on the right, and the whole of the hillside was formerly faced with smooth-dressed stones at a steep angle. The castle still forms the residence of the governor of the Belâd el Beshara, a considerable district in the centre of Northern Galilee.

Hugues de St. Omer, Prince of Tiberias, founded the castle about the year 1107, in order to protect the road from Tiberias to Tyre. After the death of that prince the castle was given to a family who took their name, De Toron, from it, and of whom there are still descendants.

The place was taken twice by the Mahommedans-first in 1187, by Saladin, and secondly, in 1219, by the Sultan Melek Mohadam, who destroyed it. It was rebuilt in 1229, and became a cause of dispute between the Teutonic knights and the heirs of Philip de Montfort, who by his marriage had obtained the right of lordship over the castle.

II. Külat Kurein, the Crusading Castle of Montfort.-This castle was situated in the hills to the north-east of Acre, on the southern eliffs of the Wâdy el Kurn, in which there is a fine stream of water. Like many other Crusading castles, its site was chosen on a narrow rocky ridge, separated by deep valleys with steep sides from the surrounding country.

The view is taken from the south-west, and is the first photograph taken of this castle.

On the east the narrow rocky ridge was cut artificially into a deep ditch, thus defending the most vulnerable part of the fortress. On this side of the castle the keep was situated, built of immense blocks of stone, beautifully dressed and drafted. This masonry resembles the larger work in the western tower of the castle of Banias.

The rock below the castle was faced with large masonry, as can be seen on the right of the picture below the keep.

The ridge was not cut away to receive the castle, the outer walls were built some little way down the slope, the same as at Belfort and Banias. Thus a solid building was formed, the core being of natural rock. In this enormous cisterns were excavated, and on it the upper stories rested firmly.

The photograph shows how the castle was built in steps, the highest on the right being the keep, the next the barracks and dwelling-places of the garrison, at the extremity of which was a large chamber with a centre octagonal column that can be seen in the view. This was probably the chapel. The next step was a courtyard defended by bastions 
and loopholed towers. From that the hill falls steeply 560 feet to the valley below.

The first account in history of this fortress, in 1229, relates how the Grand Master of the Teutonic Knights, Herman de Salza, by a treaty with the Lords of Mandelée, became possessed of the fortress of Montfort. The castle was rebuilt, and received the name of Starkenburg. It was designated as the treasury of the Order, and the grand treasurers became guardians of it. Four of their names are known :

Helmerich, 1223 A.D.

Conrad, 1240 A.D.

Jean de Nifland, 1244.A.D.

Jean de Saxe, 1270-1272 A.D.

The Sultan Melek ed Dhahr Bibars made an unsuccessful attack upon the fortress in 1266. In 1271 he returned, and was successful. The Arabian historian, Ibn Ferât, describes the siege minutely, and relates how the castle was taken in stages, first the lower courtyard and so on. The Sultan destroyed the castle, and left it probably in very much the condition it now is in.

III. Kül'at esh Shukîf, Crusading Castle of Belfort.-Situated high on the precipitous cliffs, 1,500 feet above the River Litâny, this castle is one of the most prominent and finest remains of Crusading times in the country. A little over two miles to the south, the river makes a curious bend at right angles and cuts through a deep gorge to the sea a little north of Tyre, forming the northern boundary of the survey.

The view is taken from the east, showing the River Litâny and the precipitous hill on which the castle is placed.

The form of the castle itself was determined by the site; it is long and narrow and in two portions; the lower of these is built on a terrace overhanging the precipice, the upper portion on the top of the ridge of rock.

The.southern and western points are protected by deep ditches cut in the rock, and the scarp was faced with blocks of dressed stone; on the southern side there are two round towers that form a prominent feature, as the facing has been carried round symmetrically, gradually increasing in size towards the base.

The entrance was from the south, opening from the village that formerly occupied a plateau of rock at that side of the castle, and was protected by an outwork built by the Knights Templar; it led into the lower court of the castle, and from this a narrow ascent, cut out of the rock, had to be followed, entirely commanded by the upper works. This led to a gate at the southern end; on passing this obstacle, an entrance was obtained to a large court or "place des armes; " from this a vaulted passage led to the upper fortress, and after that the keep, which was massively built on the top, might hold out for some time.

The masonry is very massive drafted Crusading work, with some Saracenic patching, which has mostly fallen to ruins.

The Arabian historian, Muhammed Ezz ed din Shedad, relates that 
the Kül'at esh Shukîf was taken by Fulke, king of Jerusalem, in 1139 . At that time it was in the possession of the Emir Shehab ed Din. It was made over to the Lord of Sidon, and from that time the title was Lord of Sidon and Belfort. In 1192 Saladin besieged this castle, and as the siegeis seemed likely to be long, and success was uncertain, he resorted to a ruse. He demanded an interview with Count Raynauld of Sidon, who was defending the fortress, and sent his ring as a guarantee of safe conduct; when the count came he was seized and imprisoned, and as he would not give up the fortress he was taken in front of the walls and tortured; but, instead of counselling the defenders to surrender, he ordered them to hold out to the last. The count was sent to prison at Damascus, and after two years' siege the castle surrendered with the condition of their lives and the liberty of Count Raynauld.

In 1240, a treaty with Salah Ishmael, Prince of Damascus, gave back Belfort to the Crusaders, but the prince had to come himself and besiege the castle in order to carry out his promise. It was then rebuilt and sold to the Knights Templar.

The castle was finally taken by the Sultan Bybars Boudoukay the 26th April, 1268.

IV. Kül'at Srıbeibeh, or Kül'at Nimrûd, Crusading Castle of Banias.This castle was situated at the extreme north-east of Palestine proper, overhanging the town of Baniâs, the Panium of Josephus and the Cæsarea Philippi of the New Testament. It must have been within sight of this castle that the Transfiguration of Our Lord took place.

The site of the eastle is a narrow rocky ridge, with deep valleys on the northern and southern sides. It is certainly the largest and best preserved ruin of its class in the country; it measures 1,450 feet east and west, by an average width of 360 feet. The only approach to the castle is from the east, by a narrow pathway amongst the steep rocks that rise to the castie; this path leads along the southern front past the keep, and then enters by a Crusading gateway in a square tower.

The view is taken from the south-east, and on the right are the ruins of the citadel, which is still in a fair state of preservation, many vaulted chambers and passages being still perfect. The wall was defended by round towers and strongly built of drafted stones, the bosses left rough, on which there are a number of masons' marks. At the western and north-western side there was another citadel of very much larger stones, beautifully dressed and drafted; some of these measure 8 to 10 feet long by about 4 feet square. In this the most ancient portion of the castle, the pointed arch was everywhere employed.

There are a number of Arabic inscriptions cut on more ancient work, detailing how different princes rebuilt portions of the castle; but very little Saracenic work remains, the old ruins holding out better than the patching attempted by these princes. The earliest dates from 625 A.H., equivalent to 1227 A.D., and details how Melek el Azis 
Murâd ed Dîn, nephew of Saladin, rebuilt the eastern portion of the castle. Immense cisterns supplied the garrison with water.

There is no history of the castle before the time of the Crusades; it then followed the fortunes of other fortresses in Palestine. It was conquered by Nûr ed Dîn, prince of Damascus, when the town of Baniâs fell into the hands of the Saracens ("William of Tyre," Book XV., ch. viii.).

V. Kül'at Hûninn, Crusading Castle of Chateau Neuf.-This castle was situated in an indentation of the hills overhanging the Jordan valley, and with Belfort, Toron, and Banias, protected the northern and eastern frontier of the Crusading kingdom.

The view is taken from the north-west, and shows the castle and village of Hûnîn. The castle consists of a large courtyard surrounded by walls defended by round towers. On the north-eastern side there was a place des armes overhanging the steep descent of the hill. The whole of the north-western portion was taken up by a square citadel, surrounded by a rock-cut ditch of considerable dimensions, and showin excellent workmanship. The older portion of the masonry shows drafted stones, with rough bosses, and some without draft, as at Tibnin. The citadel was reached by a drawbridge communicating with the courtyard. in the interior. The castle has been much destroyed and rebuilt by Saracenic workmen, and their work is also ruined and mixed up with the original masonry in hopeless confusion. A Crusading gateway leads into the village. There is very little history of this castle. An Arab historian, Ansel Jelil, relates that after the battle of Hattin, Saladin detached a chief to invest the castle of Hûnin. The garrison were reduced by famine and surrendered. It was probably built about the same time as Toron, and seems to fulfil the required position of the Crusading castle of Chateau Neuf.

VI. Kül'at Jiddîn. - A Saracenic castle built by Dhahr el 'Amr during his rebellion against the Turkish Government. Some parts of the castle are still in a fair state of repair, though now it is entirely deserted and is rapidly falling to ruin. The castle shows some good Saracenic masonry, and was protected by a wall with round towers on the eastern side.

The view is taken from the north.

VII. Large Synagogue at Kefr Bir'inn.-This is the most perfect example of the façade of a Galilean synagogue remaining in the country. The south front is almost in a perfect condition, as shown in the photograph. The history and date of these synagogues, with some description of the peculiar porch of this synagogue, which resembled the gate Tadi in Herod's Temple, as described in the Talmud, are given in another paper in this Quarterly, on "Synagogues of Galilee."

VIII. Central Doorway of Ditto.-This view shows the mutilated remains of the sculptured Pascal lambs that once decorated the main entrance to the synagogue, also the finely-cut representation of a vine and grapes over the doorway. 
IX. Gateway of Small Synagogue at Kefr Bir'im.-This fine gateway stands alone, the rest of the synagogue having disappeared. Major Wilson, R.E., was able, by means of excavation, to trace the walls of the building, and to show that this synagogue, unlike the majority, had only two rows of columns (Quarterly Statement, No. 2, April, 1869). The square Hebrew inscription on the lintel has been read by the late Mr. Emanuel Deutsch, "Peace be upon this dwelling-place." The remains of sculptured figures of lambs are still traceable, though much mutilated, on the lintel.

The gateway measures 11 feet high, and is 5 feet broad; the lintel is 9 feet 7 inches long, by 2 feet 9 inches by 2 feet 6 inches deep.

Both doorposts have been much shaken, but that on the left in the view has been shifted bodily in, as can be seen by the mouldings. How the gateway stood under this treatment, which was probably caused by earthquake, is a marvel.

X. Synagogue at Meiron.-Next to Kefr Bir'im the façade of this synagogue is the most perfect remaining specimen in Galilee. It was built on a rocky ledge, the west side and floor being excavated out of the rock. Traces of the position of the pillars in the building are still to be found on the floor. From this a plan of the building has been constructed. The eastern and southern walls, built on unstable made-up ground, have been entirely destroyed by time.

Meiron was an early sacred place to the Jews after the destruction of Jerusalem by the Romans. It is the traditional burial-place of Shammai and Hillel, and later the great Rabbi Simon Bar Jochai was buried here. Pilgrimages are made to his tomb by Jews in all parts of the world, and the scene of one of these annual meetings is described in my report from Meiron (Quarterly Statement, July, i877).

The principal gateway is 14 feet high to the top of the lintel, and 6 feet wide. The lintel is 4 feet 2 inches high.

XI. Lintel of Synagogue at Nebratein.-On this lintel is seen the Jewish form of the seven-branch candlestick, and a Hebrew inscription somewhat difficult to decipher. The remains of the synagogue are traceable, and on the pedestal of one column there is a carved representation of a hare, an unclean animal to the Jews.

XII. Newly Discovered Synagogue at Süfsâf.-This is one of the two newly discovered synagogues found during the course of the survey last year. The remains seen in the photograph consist of a sculptured lintel built in over the doorway of the modern mosque of the village, and surmounted by a carved niche surrounded by ornamenteu voussoirs.

The lintel measures 5 feet long by 1 foot 8 inches high, and on it two rams' heads are sculptured on either side of a wreath with surrounding ornamental scroll work.

It appears probable that this lintel formerly belonged to one of the smaller of the three doors common to these synagogues; the niche is placed over it as it probably was in the original building, but the ornamented voussoirs probably came from the larger doorway, as they 
do not fit round the niche. The probable voussoirs of the smaller door'ways are seen built into the wall on the left.

With such an ornamental lintel for the side doors, the great one of the central doorway, if found, would probably be very elaborate.

XIII. Colonnade at Belat. - On the top of a high wooded ridge in the wildest part of Galilee are the ruins of what must have been a noble temple. The remains of sixteen columns are apparently in situ, and some of them still bear an architrave. The original building was formed of a double row of twelve columns, 16 feet apart, and with a varying intercolumnar distance of from 6 feet to 8 feet; the total length being 99 feet 11 inches. This is surrounded by a wall at a distance of 7 feet. The columns and architrave make a total height of 14 feet. The entrance was probably on the eastern side, where two columns are squared on the outside. The direction of the colonnade is within 12 degrees of north and south, and the end columns are doubled like those in synagogues. The view is taken from the southern end. The architrave shows no signs of mouldings, and the capitals and pillars have an archaic form; they are very much weathered by exposure.

The origin of this singular ruin is discussed in the paper on "Synagogues of Galilee" in this Quarterly.

XIV. Masonry Tomb at Kades.-This is probably a Roman tomb. Four massive piers supported arches, and may have been surmounted by a dome. In the spaces under the archas masonry loculi are built. The building measures $3 \check{5}$ feet square, and a plan has been published (Quarterly statement, No. 3).

The view is taken from the south-east, and shows the moulded doorway and niche on the right.

XV. Temple of the Sun at Kades.-The view is taken of the eastern façade of the temple. The great doorway and two smaller doorways are seen with their ornamented lintels and doorposts. On the left is a small niche, with traces of a robed figure cut in it, and in a cor:esponding position on the right there is a small hole leading into a recess in the wall, by means of which oracles might be given or money passed through to the interior. The ornamental lintel lying in front in the photograph shows the winged delineation of the sun as at Baalbek.

The building forms a rectangle, 63 feet by 75 feet, and one of the doorposts standing is a monolith measuring 15 feet high. The view is taken from the sonth-east.

XVI. Ditto.-This photograph of the front gives a better view of the ornamentation on the doorpost, and also shows a large Corinthian capital, that probably surmounted one of the two enormous columns that formed the portico of the temple, like those in Syria. It is taken from the north-east.

XVII. Hiram's Tomb.-This tomb is situated in the low hills running down to the sea on the east of Tyre.

It is the traditional tomb of Hiram, king of Tyre, in the days of 
Solomon, but is unlikely to be the real place of sepulchre of that monarch. The number of sarcophagi in this part of the country is very large, and there must have been formerly many monuments equalling, if not surpassing, the present one. This, however, is the most perfect tomb of this kind existing, and gives some idea of the grandeur of this mode of burial.

The sarcophagus, cut out of a solid mass of limestone, is placed on a base 9 feet 8 inches high, formed of three courses of whitish limestone in large blocks. The upper course, projecting 6 inches all round, makes a platform 9 feet 9 inches by 14 feet 2 inches; on this the sarcophagus, measuring at its base 7 feet 9 inches by 12 feet 2 inches, stands. The lid is made with a ridge, and is 3 feet 7 inches high in the centre.

Immediately on the north side of the monument, two flights of a few rudely-cut steps lead to the door of an artificially-made cavern, 8 feet wide by 10 feet long. The view is taken from the south-east, and shows the Freemasons' mark that some too enthusiastic member of the craft. has lately scratched on this monument.

XVIII. Cathedral at Tyre.-The cathedral occupies the south-east corner of the modern wall of Tyre. It is now in ruins; only the eastern portion with the three apses remains. The northern one of these is the most perfect.

The inside dimensions of the church were 214 feet long by 82 feet wide; the central apse has a diameter of 36 feet. The transepts project 15 feet, and have side chapels in them with small apses made in the thickness of the wall.

The masonry is small, of soft stone, fixed in strong cement, and having some masons' marks.

In the interior there are magnificent monolithic columns of red granite, measuring 27 feet long. They were probably taken from some ancient temple, and show the form of double column peculiar to synagogues. One of these, and fragments of others, are to be seen in the foreground of the photograph. The rest of the interior decorations appears to have been of white marble.

The windows of the apses are ornamented on the outside by zigzag tracery.

The cathedral, according to M. de Vogué, was Crusading, dating from the latter half of the twelfth century. It probably occupies the site of the church built by Paulinus, and consecrated by Eusebius $323 \mathrm{AD}$., in which the bones of Origen and the Emperor Frederic Barbarossa were buried. Some excarations were attempted in 1874, to find these tombs, but without success.

XIX. The Source of Jordan.-The great spring at Banias has from an early date been allowed to be the real source of the River Jordan. The water gushes out of a cave situated in the face of a cliff of limestone rock about 100 feet high. Earthquakes have shaken down great fragments of rock, so that the base of the cliff has been blocked up and the 
cave almost entirely ruined. The water now finds its way through this mass of stones by different channels, uniting immediately below the déoris, and forming at once a strong stream that irrigates the surrounding gardens and makes Banias the most beautiful place in Palestine. By this stream stood the ancient Panium of the Greeks, and here Herod erected a temple in honour of Augustus. There are three votive niches in the face of the rock, one of which is visible in the photograph. They were once much higher above the ground than now. Two of them bear Greek inscriptions, in one of which "Priest of Pan" is mentioned. This was also the site of Cæsarea Philippi of the New Testament, and it has been suggested that this rock was intended in our Lord's words, " Upon this rock I will build My church, and the gates of hell shall not prevail "against it" (Matt. xvi. 18).

XX. Palestine Survey Camp at Banias.-The magnificent olive trees formed a delightful shade, while the trickling stream of water led through our camp, making everything cool and delightful. Under the roots of these great trees we found remains of tesselated pavement in different coloured marbles, showing that some ancient building once occupied this site. A hundred yards to the east of our camp was the great source of Jordan, clear and sparkling, and delightfully cold.

H. H. KITChener, Lieut, R.E.

\title{
THE LAND OF MIDIAN AND ITS MINES.
}

\author{
Reprinted from the "Times."
}

Alexandria, April 2ith.

THe return of Captain Burton and his party from the Land of Midian at the beginning of this week is already known by telegraph in England. The object of the expedition was to examine into the mineral wealth of the country, which hitherto has been very little visited by travellers, and is only imperfectly known to geographers. Yet the minerals of Midian were known both in Biblical and classical times. Everybody remembers how Moses, when he fled from the face of Pharaoh, dwelt in the land of Midian and married the priest's daughter; and how, notwithstanding this alliance, the children of Israel, after the Exodus, vexed by the wiles of the Midianites, made war upon them and slew their kings, and burnt their cities and their goodly castles, and spoiled them of "gold, silver, brass, iron, tin, and lead," and " jewels of gold, chains and bracelets, rings, earrings, and tablets;" and now Moses ordered the wrought jewels of gold to be brought into the tabernacle as a memorial. It is equally well known, too, how the Romans long afterwards again worked the mines whence these metals were dug, and many are the traces of their work which Captain Burton has recently found. Yet next to nothing is now known of the country; its wild wastes of 